\title{
WIPOZER, Fish Freezer Machine Based Wind Power as an Alternative Preservation on the Fishermen Vessels
}

\author{
Diang Sagita, Andriyana, and M Munajat
}

\begin{abstract}
Indonesia is an archipelago country which has very large of water area. According to [1] the distance of Indonesia's beach achieves $95,181 \mathrm{~km}$ with 5.8 million square $\mathrm{km}$ of sea area. According to $F A O$ (2007), the total world fisheries production reached 145 million tons that is still dominated by capture fisheries (64\%) and aquaculture (36\%). Indonesia occupied the third position after China and Peru as a country which has the highest capture fisheries production in the world. Handling of fresh fish is one of important role in the production process of the fishing catch, because the purpose is to strive so that the freshness of the fish can be maintained until reach the consumers. However, the handling of fish on board fishing vessels generally still using traditional method with limited facilities. The fishermen rarely to freeze the fish catches. Base on the problem, so it is needed a technology in terms of preserving fish while fishing on the ocean so no longer need to carry ice block moreover using a dangerous substance like formaldehyde. One of the innovation is Wipozer, fish freezer machine based wind power that can be installed on a fishing boat while traveling. The potential big wind at the sea can be converted into electrical energy which is later used as a source of energy for the freezer. The fishermen do not have to bring the ice block much less formaldehyde as a preservative, the fish will be more fresh and healthy in the freezer.
\end{abstract}

Keywords-energy, fish, fishermen, freezer, wind

\section{INTRODUCTION}

Indonesia is an archipelago country which has very large of water area. According to [1], the distance of Indonesia's beach achieves $95,181 \mathrm{~km}$ with 5.8 million square $\mathrm{km}$ of sea area.

This condition makes the majority of the Indonesian people especially for people who lives at the coast area have livelihoods as fishermen, both traditional or modern fishermen. Traditional fishing usually using many kind of techniques, one of the way is working with groups and hunting for fish up to days. The process of handling fresh fish is very important role because the primary purpose is to strive so that the freshness of fish can be maintained as long as possible. Preserving fish by fishermen on the boats generally using ice block which brought at the coast, but there are a lot of fishermen who use unorthodox way i.e. by using formaldehyde as a preservative. This is important to give more concern about that considering formaldehyde is highly dangerous if consume by humans.

Base on that condition so need a technology in terms of preserving fish while fishing on the boat/vessel in order to no

Diang Sagita, Andriyana, and M Munajat are with Bogor Agricultural University, Indonesia longer need to carry ice block moreover using formaldehyde. One of innovation called Wipozer, fish freezer machine based wind power which can be installed on a fishing boat while traveling. The potential for big wind at sea can be converted into electrical energy which is later used as a source of energy for the freezer. The fishermen do not have to bring the ice block much less formaldehyde as a preservative, the fish will be more fresh and healthy in the freezer.

\section{LITERATURE REVIEW}

\section{A. Fish}

According to FAO (2007), the total world fisheries production reached 145 million tons and it is still dominated by capture fisheries (64\%) and aquaculture (36\%). Contribution of developing countries to the total world production reached $80 \%$, and the production of cultivating more than $90 \%$. Indonesia occupied the third position after China and Peru as a country which has the highest capture fisheries production in the world [1]. Based on the decision of the Minister of marine and Fisheries the number KEP. 45/DOWNLOAD/2011, sustainable fish resource potential in Indonesia is currently 6.5 million tons/year

\section{B. Handling of Fresh Fish}

The fishermen in terms of fishing use many kind of boats like regular Paddle boats, small motor boats and standard vessels [2]. The fishermen usually do fishing no more than a day and they rarely to freezing the fish. Actually they realized that to get the high sale price needed to maintain the freshness in top condition. but due to the limited capabilities, facilities and ability of the purchasing ice in large quantities so that the handling of fresh fish become insufficient [3].

\section{Wind Turbine}

Wind turbine is the tool used to generate electric power from wind. Wind energy can be used as an energy source using windmill. Wind potential that can be exploited is at rate of speed about $2.5-25 \mathrm{~m} / \mathrm{s}$ [4]. Overall wind energy potential in Indonesia's is not too high, but on the basis of surveys and measurement of wind data that have been conducted since 1979 [5], many prospective areas that have wind speeds with annual average of 3.4-4.5 m/s or have energy between $200 \mathrm{kWh} / \mathrm{m}$ up to $1000 \mathrm{kWh} / \mathrm{m}$. This potential has been used for small-scale power plants about $10 \mathrm{kw}$.

Wind turbines have advantages such as have good durability and easy to maintenance, and usually just require checking and refill the engine oil at regular intervals. A wind turbine consists of several components such as gearbox, brake systems, 
generators, energy storage and rectifier-inverter.

\section{METHODS}

\section{A. Research Procedure}

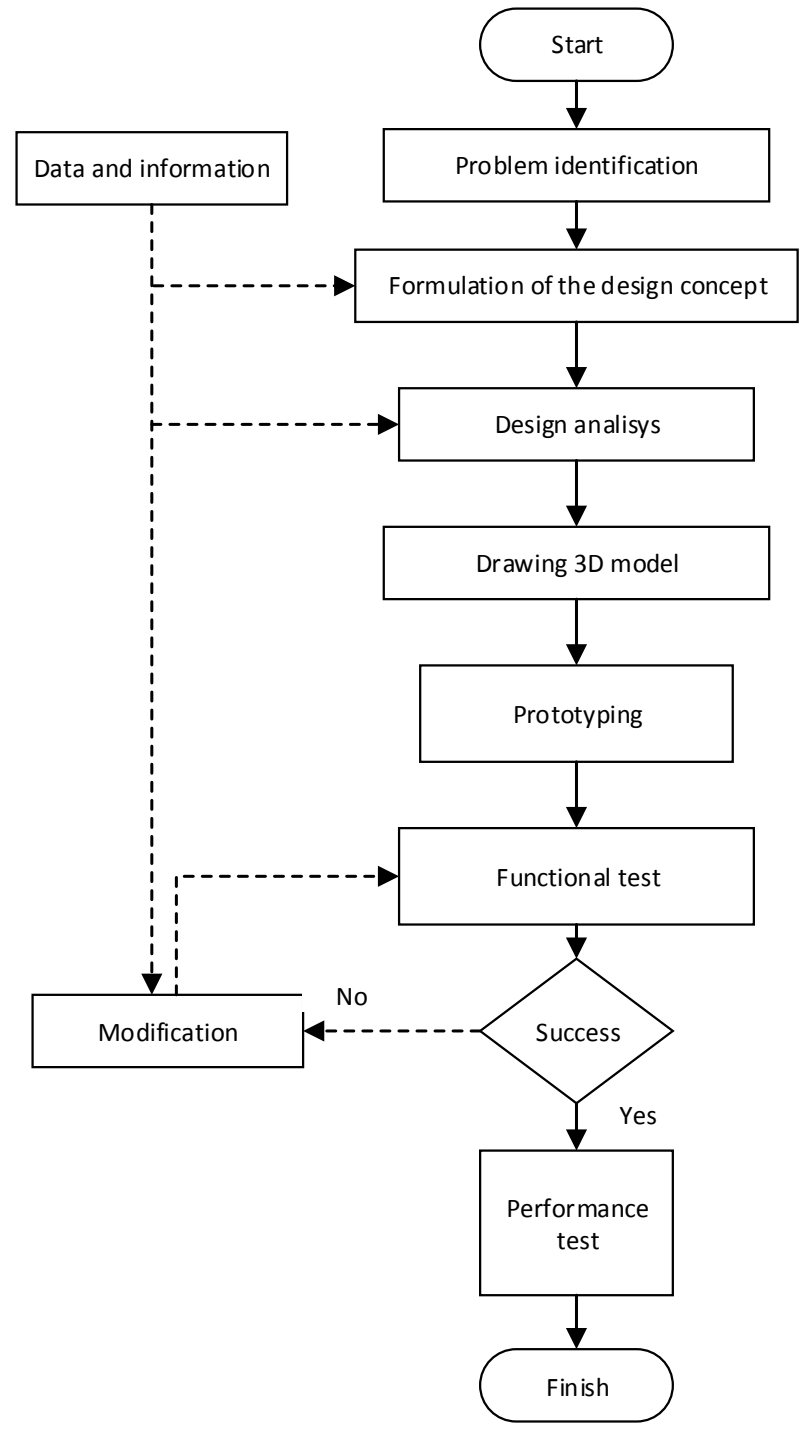

Fig. 1: Flow chart of research

\section{B. Functional Design}

Functional design of the machine is important to be considering. In the design of wind-powered fish refrigerators, there are some parts that needed to be established. The first is boat as a media of fish freezer, then the engine generator, electric power and the freezer machine. Parts of the machines consist of (1) boats, small boats with width of 2-3 metres and a length of 7 meters. (2) the electrical power plan consists of a wind turbine, generator, stabilizer, and Power supply. (3) storage box fish (Freezer).

In the manufacturing of fish freezer machine based wind power (wipozer), it was necessary to consider some aspects. These aspects include the quality of machine and the suitability of the wind speed at sea with a series of machines based on mathematical formulation. Windmill must be strong and sturdy, stainless, constructed from steel beams or pipes. Then the other components combined with a strong mounting system to withstand jolts and wave.

\section{RESUlTS}

\section{A. Materials and equipment selection}

The equipment used in the process of designing wind-powered machine consist of grinder, tool boxes, rivet, hacksaw, welder, and hammer. And the materials consist of generators, iron plates, iron pipe, rivet, bolt, nut, pulley, wire, cable, freezer, stabilizer, power supply, and the gear box.

The selection of materials was determined based on the properties of the materials. The materials used for the frame is low carbon steel. Low carbon steel has a carbon content of $0.03 \%$ and the power of its retained $40 \mathrm{kgf}$ per square millimeter [6]. The turbine used aluminium material in order to the weight of the turbine not too high. Aluminium has a modulus elasticity $100 \times 109 \mathrm{~N}$ per square meter.

In addition, the supporting components of this design is the power generator. In this case, it was using an AC electric motor with voltage of 220 . The output power then stabilized by stabilizer before use to turn the freezer for preserving fish.

The type of windmill used are savonius type because it's quite effective in utilize the wind around and doesn't take too much place. The size is not too big because it is considering the size of fishing boat. Generator used is electric motors with low rpm because the motor contains gearbox. The voltage can be generated up to $220 \mathrm{~V}$ with turbine rpm about $100 \mathrm{rpm}$. Stabilizer is used to stabilize the flow of electricity because electricity generally volatile and not constant.

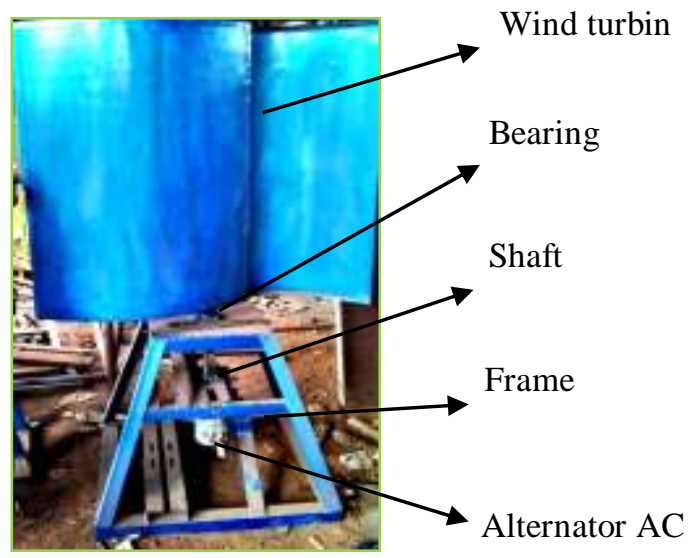

Fig. 2: Prototype of wipozer

The figure above is a prototype that has been constructed and ready to implemented in the fishing boat/vessels. For the freezer component, we use the existing commercial freezer, we use an existing freezer because we know that our science still not enough to be able to make it. Our main focus is utilizing wind energy at sea in order to be useful for fishermen. However, if possible, in the future will be developed and manufactured the freezer by ourselves so overall are really genuine results from us.

Mechanism of fish freezer machine is by utilizing wind energy at sea which has a speed of $3.4-10 \mathrm{~m} / \mathrm{s}$ or more to rotate 
the windmill which have diameter of $50 \mathrm{~cm}$ and a height of 100 $\mathrm{cm}$. then, windmill connected to a generator to produce electricity. In order to the electricity has a stable power then after the generator produce electricity, it is connected to the stabilizer. Stabilizer then connected to the energy storage (power supply) before used by fish freezer.

Fish freezer expected to be working when the fishermen went to the sea and returned home. So the freshness of fish catches by fishermen can be maintained.

\section{B. Technical Analysis}

\section{- Power}

The freezer which used is freezer with 220 volt of voltage and 100 watts of power with capacity of 100 litres and has weight of $30 \mathrm{~kg}$. Then, the blades have size 1 square metre, wind speed assumed $10 \mathrm{~m} / \mathrm{s}$ (large scale), the air density $1.2 \mathrm{~kg}$ per cubic metre. Then the power plan determined as follows:

$$
\begin{aligned}
& P=1 / 2 \rho A v^{3} \\
= & 1 / 2 \times 1,2 \times 1 \times(10)^{3} \\
= & 600 \text { watt }
\end{aligned}
$$

Efisiensi $30 \%=60030 \%=180$ watt

With $P$ for power (watt); $\rho$ for air density $\left(\mathrm{kg} / \mathrm{m}^{3}\right) ; A$ for area of turbine $\left(\mathrm{m}^{2}\right)$; and $v$ for air velocity $(\mathrm{m} / \mathrm{s})$.

- Calculation of the speed rotation of the propeller

Calculation speed (rpm) aims to calculate the potential propeller rotation. Here is the calculation:

if the air velocity assumed $10 \mathrm{~m} / \mathrm{s}$, and the radius of propeller 0,5 metre so:

$$
\begin{aligned}
v / r & =2 \pi n / 60 \\
& n=60 v / \mathrm{r} 2 \pi \\
& =60 \times 10 / 0,5 \times 2 \times 3,14 \\
& =191,12 \mathrm{rpm}
\end{aligned}
$$

With $\mathrm{n}$ for rotational speed (rpm); $\mathrm{r}$ for radius of turbine (m). That value of rotational speed was more than enough to generate electricity from the generator, this means that the speed of $10 \mathrm{~m} / \mathrm{s}$ is very good.

\begin{tabular}{|c|c|c|c|}
\hline No & Time (minutes) & RPM & Voltage (Volt) \\
\hline 1 & 1 & 30 & 6 \\
\hline 2 & 1 & 60 & 62 \\
\hline 3 & 1 & 88 & 111 \\
\hline
\end{tabular}

\section{Testing on Laboratory Scale}

Testing of the machine has done by twisting the blades so that the voltage generated. The parameters used in these trials is propeller rotation, voltage, and time. Following is the result of the test:

TABle I: Results OF PERFORMANCE TEST

The trial results have not yet reach the desired voltage that is $220 \mathrm{~V}$. Factors affecting those results is the lack of wind at the moment of trial. The generator can generate up to $220 \mathrm{~V}$ voltage when the rpm reached the value of 120 or more, that is the require speed to make the generator can be working well. But overall, the trial results are sufficient because the voltage still can be generated at the medium rpm.

\section{Implementation on the Vessels}

Our partners are fishermen in Tanggamus Regency, South Lampung, Indonesia. socialization of the technology has been conducted on $5^{\text {th }}-8^{\text {th }}$ July, 2014. The socialization done with performance test of the machine that been installed on the fishing boat and then asking for opinions about our technology to the partners. Partners very interested and happy with the freezer machine we've established because they said it can help them in terms of preserving fish and also advancing the technology in the terms of marine especially for small fishermen.

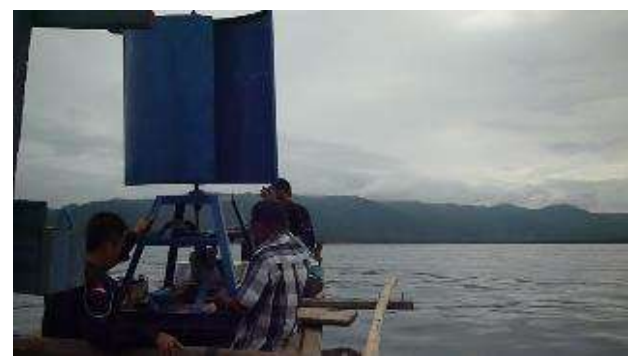

Fig. 3: Implementation of wipozer

\section{- Excellence}

Manufacturing and installation is very easy. The machine also easy to be implemented in the fishing boats. This machine also utilizes renewable energy so that are environmentally friendly.

\section{- Innovation}

Currently the fishermen still using ice block to preserving fish on the boats/vessels, and that is troublesome. Then wipozer were underway that could preserve the fish with energy from wind sources.

\section{- Kemanfaatan}

Benefit from this machine is the fishermen no longer to buy and bring the ice block moreover formaldehyde. Wipozer can be applied on their boat so that they will be more comfortable without carrying the ice. Economically the costs of using wipozer is cheaper than using ice block in the long term.

\section{CONCLUSION}

Fish freezer machine based wind power is very helpful and needed technology for using by fishermen. Fishermen can be more comfort and easier in the process of cooling fish on the vessels. But there is still has lacking because the performance of this machine must considering the weather and wind velocity.

Although the result of this machine is not maximal yet, but this research will become initial step to develop a better technology for the same meaning. The study also included in order to socialize the use of renewable energy conversion technology that can be directly applied in the community and also the first step to advancing marine technology in Indonesia. So for the future, it was needed to conduct the next research and for more specific development. 


\section{ACKNOWLEDGMENT}

The authors wish to thank Engineering Research Fund, Ministry of Research and Technology and Bogor Agricultural University (BAU) for financial support, thank to Mechanical and biosystem engineering Department and also for all the people who support this research.

\section{REFERENCES}

[1] Badan Pusat Statistik (September 2013), Statistik Sumber Daya Laut dan Pesisir 2012 [online]. Available: http://www.bps.go.id.

[2] R.B. Mulyanto etc., Kapal Perikanan (Pengukuran dan perhitungan), Semarang: Balai Besar Pengembangan Penangkapan ikan, 2012.

[3] A. Irawan, Pengawetan Ikan \& Hasil Perikanan, Solo: CV Aneka, 1995.

[4] U. Aswathanarayana and S. R. Divi, Energy Portfolios, London: CRC Press, 2009.

http://dx.doi.org/10.1201/9780203876602

[5] Badan Meteorologi Klimatologi dan Geofisika (June 2014), Prakiraan Kecepatan Angin Stasiun Panjang [online]. Available: http://www.maritim. bmkg.go.id.

[6] S. Surdia and S. Saito, Pengetahuan Bahan Teknik, Jakarta: Pradnya Pramita, 2000.

\section{Biography}

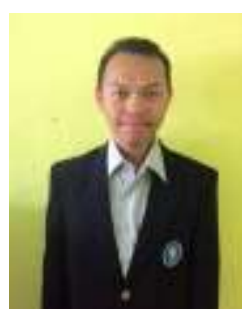

Diang Sagita. Born in Sukabumi, Indonesia December $15^{\text {th }}, 1994$. The author's graduate from high school in 2012 from SMA Negeri 1 Pelabuhanratu and in the same year accepted at Bogor agricultural University. The author chose the course of Mechanical and Biosystem, Faculty of agricultural engineering and technology. During the lecture, the author actively follows the officials of the Organization and one as Vice Chairman of the association of Agricultural Engineering student (Himateta) in 2013-2014 and as a member of the Engineering Design Club (EDC) IPB in 2014 and 2015.

During the lecture, the author also actively follow the paper competition at the national level as in the year 2014 successfully became a finalist on the scientific Agricultural Student Weekend, Indonesia (PIMPI) and by 2015, the author being a third place at the Competition of Designing Agricultural Machine which environment friendly (SUPERNATURE) held at the University of Padjajaran, and in the same year the author became a finalist in the event at the 28th PIMNAS University of Halu Oleo, Kendari, Southeast Sulawesi, Indonesia. The author does a practice field in PT Rajawali II Unit PG PG Jatitujuh entitled "Application of the engine on the cultivation and processing of sugar cane in PT Rajawali II Unit PG PG Jatitujuh, Majalengka". As one of the conditions obtained a Bachelor of engineering, the author completed the thesis entitled "Design and performance of the Unit Perontok of corn on Corn Harvesters Machine". 